\title{
Energy Sensitive Designs: Evaluation and a Proposed Model for Residential Buildings in Warm Humid Climate
}

\author{
Oyeyemi Arowolo (Corresponding author) \\ Dept. of Architecture, Obafemi Awolowo University \\ Ile-Ife Osun State Nigeria
}

Tel: 234-803-960-3585Ｅ-mail: arowoloseun@gmail.com

\section{Kola Ajibola}

Dept. of Architecture, Obafemi Awolowo University

Ile-Ife Osun State Nigeria

Tel: 234-805-752-0823Ｅ-mail: kwoleajibola@yahoo.com

Bode Orola

Dept. of Architecture, Obafemi Awolowo University

Ile-Ife Osun State Nigeria

Tel: 234-802-322-7190Ｅ-mail: olabode.abiodun30@gmail.com

Ayomide Omolola

Dept. of Architecture, Obafemi Awolowo University

Ile-Ife Osun State Nigeria

Tel: 234-803-376-8662Ｅ-mail: ayomidey@yahoo.com

Received: March 28, 2016 Accepted: April 17, 2016

doi:10.5296/emsd.v5i1.9215 URL: http://dx.doi.org/10.5296/emsd.v5i1.9215 


\section{Abstract}

The warm humid climate of Osogbo is characterised by its high humidity, relatively high temperature, and four distinct major seasons. Hence, this paper is aimed at assessing the climatic responsiveness of the five major residential building design types in Osogbo with a view to develop an energy sensitive design framework for a warm humid climate. This involves synergizing the comparative advantage discovered in each design type predicated on the Mahoney Tables assessment criteria. Data were obtained through measurement and assessment of the design characteristics of 209 residential buildings design types in Osogbo. Four political wards with the predominance of each of the five building design types (namely; traditional houses, rooming-apartments, apartments, bungalows and duplexes) were purposively selected. Buildings were assessed on layout (orientation), spacing between buildings, air movement (inlet/outlet), size of openings (fenestration), wall materials (thermal transmittance) and roof characteristics (thermal reflectance and transmittance). Findings revealed that the bungalow designs had better orientation compared with the other buildings surveyed. The duplexes had better spacing; the rooming-apartment designs had adequate air movement. Likewise approximately $70.0 \%$ of the surveyed residential buildings had adequate fenestration. The result also revealed that approximately $90.0 \%$ had their external walls constructed with hollow blocks of low thermal transmittance and lastly $15.3 \%$ of the total residential buildings had roof of high thermal reflectance and low transmittance. Out of this percentage, the duplex building designs accounted for the majority. Finally, an energy sensitive design framework was evolved from the comparative assessment of the five residential building design types analysed.

Keywords: Climatic Design, Energy, Fenestration, Opening, Orientation, Roof, Spacing, wall

\section{Introduction}

Over the years there has been conscious effort to reduce reliance on active energy use for comfort. One may expect that Nigeria should have keyed-in into the trend with suitable improved energy sensitive designs considering the fact that energy demand is increasing geometrically (Oyedepo, 2012) but that has not been the case. Nevertheless, the few studies conducted on energy sensitive designs were largely not explicit on improving the old building designs.

Studies conducted by some researchers ( by Ogundipe and Apata, 2013; Akinbami and Lawal, 2009) are concerned with obtaining accurate wattage or values (energy audit) of active energy use in residential buildings and how it can be managed and reduced. These studies however did not result in the evolution of better designs that can be a necessary influence in reducing energy use. Furthermore some studies (Lawal and Ojo, 2011; and Ajibola, 2001) acknowledge the importance of climatic responsive designs in reducing active energy use and suggested ways of enhancing designs to be energy sensitive however the economic factors affecting a developing country like Nigeria were not considered. As a result of this observed gap this study adopted a simplistic approach in evolving the design framework taking into consideration the economic realities and psychological attachment of the populace to the 
existing building designs. Climatic responsiveness of existing building designs was assessed and the comparative advantages of passive energy utilization discovered in the building design types were synergized to evolve an energy sensitive design framework.

Over time residential building designs have evolved. The evolution of housing as described by Rikko \& Gwatau, (2011) revealed that social changes, particularly the shift from traditional community, family values to more western ways of life, have had varied impact on building designs and residential layouts. The National Bureau of Statistics NBS (2010) identified seven residential building design types in Osogbo. For the purpose of this research, five residential building design types were selected due to their numbers in the study area. The five major building design types identified in Osogbo are: (1) the contemporary rooming building, typically referred to as "face-me-i-face-you or tenement", which is characterized by rooms built facing each other in two rows, one to the left and the other to the right. The number of rooms on the left hand side usually equals the number of rooms on the right hand side, an average of 6-12 rooms per house. The house type has a common kitchen and bathroom for all tenants, many families occupy the building. Each family or tenant occupies one or two rooms; (2) the apartment type or flat, consisting of either single-level units or single-level units stacked on top of each other in multi-story buildings. They are diverse in size and design, and include two or more, bedroom floor plans, a family living, kitchen, and other conveniences, with two or more of each type arranged as detached or semi-detached multi-apartment housing; (3) the duplex building type consisting of two units per building (that is occupying two floors) either single-detached or semi-detached dwellings; and (4) single family bungalow which is a dwelling unit consisting of several rooms, family lounge(s), kitchen, and other conveniences. These vary according to the family size or structure and lastly the traditional courtyard building type. They are mostly rectangular in shape with rooms arranged round the courtyard. These residential building designs' forms are the resultant effects of the quest for a rational abode from man as influenced by culture, religion, climate, urbanization, and recently professionalism (Rikko and Gwatau, 2011).

Climatic design is developed through climatic principles that utilize the available natural energy and energy sinks. Folaranmi et al. (2013) listed the climatic principles for a warm humid climate as (1) heat protection of the buildings using appropriate techniques which are applied to the envelope of the building. This is achieved by the appropriate orientation of the buildings, (2) protection of the buildings from the sun, primarily by shading but also by the appropriate treatment of the building envelope (i.e. use of reflective colours and surfaces), (3) removal of the heat which accumulates in the building to the surrounding environment using natural means (passive cooling systems and techniques), such as natural ventilation, mostly during night-time, (4) improvement of environmental conditions in the interiors of buildings so that residents find them comfortable and pleasant (that is increasing the air movement inside spaces), (5) ensuring insolation control for day-lighting of buildings in order to provide sufficient and evenly distributed light in interior spaces and (6) improvement of the microclimate around buildings, through the bioclimatic design of exterior spaces and in general, of the built environment, adhering to all of the above principles.

Furthermore, books and literatures such as Hyde (2013), Lawal (2013), Szokolay (2008), 
Givoni (1981) and Folaranmi et al. (2013) suggested that passive cooling systems and techniques are embedded in climatic principles. Passive cooling systems and techniques use only locally available energy (that is, natural energy) sources and utilises the natural flow paths of that energy. In other words, less auxiliary equipment (air conditioners) is required to make the system to function. In an architectural design sense, the passive systems are for the cooling, ventilation and lighting of enclosed spaces. The kinds of low-grade ambient energy systems available within most building sites are actually well suited to these tasks as is evident in various traditional architectural designs prior to the discovery of electricity (Kamal, 2012). There are energy sources available locally within a building site. The effective use of these low-grade energy sources in a building requires only some careful thought and innovative design (Hyde, 2013). The basic idea of passive systems is that efficient daylight and airflow are essentials of low energy use in indoors. The criteria for a bioclimatic design were revealed in the Mahoney design recommendations for a warm humid climatic zone. On this basis the five residential building design types identified were assessed on layout (orientation), spacing, air movement (inlet/outlet), size of openings (fenestration), wall materials (thermal transmittance) and roof characteristics (thermal reflectance and transmittance) to examine their degree of conformity.

\section{Methodology}

Sampling for this study involved a purposive and random technique. Information from the Independent National Electoral Commission (INEC) indicated that there are twenty-six (26) political wards in the two Local Government Areas (LGAs) within Osogbo town (that is Olorunda and Osogbo). The National Population Commission (NPC) metadata also identified seven residential building-types within the political wards. Five residential building design types in the LGAs namely: traditional, face-me-I-face-you, apartments, bungalows and duplexes were selected for this research due to their numbers in the LGAs. Four wards with the predominance of each of the five building-types were purposively selected namely: Owode, Agowande, Ataoja 'D' and Ataoja 'E'. According to NPC (2010), a total number of 338 traditional and 1161 rooming apartment building types were identified in Owode and Agowande wards respectively while 941 apartments, 1659 bungalows were identified in Ataoja ' $D$ ' and 562 duplexes in Ataoja 'E' wards respectively. Five per cent (5\%) of each residential building type was randomly sampled. A total number of 233 design types were sampled while the assessments of 209 residential building design types were conclusive. Assessment of the selected residential buildings was carried out by experts (that is Architects) using Mahoney Tables climatic design recommendations for a warm humid climate under the following headings;

\subsection{Layout}

Building should be orientated on an east-west axis with the long elevations facing north and south to reduce exposure to sun. Determination was by a magnetic compass. The measurability of the cardinal directions was done by ascribing a quantitative value to the qualitative data, to make it amenable to statistical analysis. In order to achieve this Likert Scale was used. The four cardinal directions on a compass were sub divided into; North/South (Very good.), 


\section{Macrothink}

Environmental Management and Sustainable Development

ISSN 2164-7682

2016, Vol. 5, No. 1

North-West-North/South-South-East

(Good),

North-West/South-East

(Fair),

West-North-West/East-South-East (Bad) and West/East (Very bad).

\subsection{Spacing}

Buildings should be well spaced to allow for breeze penetration and should be five times the height of buildings. Instrument needed for determining spacing- measuring tape. Likewise, a five point Likert scale was also developed in order to measure. The spacing were rated as very adequate (spaces $>17.5 m)$ adequate $(16 m-17.5 m)$, fair $(10 m-15 m)$, inadequate $(4 m-9 m)$ and very inadequate (spaces $<3 \mathrm{~m}$ ).

\subsection{Air Movement}

Rooms should be single banked with windows in north and south walls. Alternatively buildings' air movement were also assessed if the rooms are cross ventilated. Determination was by physical observation. Air movement into the interior of the building through the assessment of their openings for cross ventilation $(\mathrm{CV})$ was rated as very inadequate $(\mathrm{CV}$ on West/East walls), inadequate (CV on West-North-West/East-South-East walls), fair (CV on North-West/South-East walls), adequate (CV on North-West-North/South-South-East walls) and very adequate (CV on North/South walls). Air velocities within the spaces were measured in relation to the layout.

\subsection{Openings}

Openings should be between $40 \%-80 \%$ of the north and south walls. Instrument needed was a measuring tape and the openings percentage determined through statistical calculation. Openings on the walls were measured with the walls and the percentage of openings on the walls was determined. The openings for the selected building were rated as very inadequate $(<30 \%$ or $>80 \%)$, inadequate $(<39 \%)$, fair $(40-50 \%)$, adequate $(51-69 \%)$ and very adequate $(70-80 \%)$. zone.

\subsection{Walls}

Light external walls are preferred with low heat transmittance. Determination was by observation and theoretical calculations in line with ISO 6946. The calculations gave the basis for rating the common external wall materials in terms of their thermal transmittance from very good (cement plastered Sandcrete hollow block/sancrete hollow blocks), good (Hollow brick), fair (Adobe block) bad (Brick) very bad (Cement plastered Adobe block).

\subsection{Roofs}

Height of roof, light roof with reflective surface and low thermal transmittance were checked for in the building under study. Determination was by observation and theoretical calculation in line with ISO 6946. Roofs were rated as very good (Attic >3m high, Steep slope/reflective colour/low transmittance value), good (Attic $\geq 3 \mathrm{~m}$ high, steep slope/colour), fair (Attic 2.45m-2.9mhigh, steep slope/colour), bad (Attic 1.8m-2.4m high, steep slope/colour) and very bad (Attic $<1.8 \mathrm{~m}$ high, steep slope/dark colour).

Each selected residential building design type was assessed by comparing the existing 


\section{Macrothink}

building design with the recommendation for a climatic responsive design for a warm humid climate from the Mahoney Tables. The assessments were recorded and rated using the Likert Scale and subjected to Statistical Package for the Social Science (SPSS) through the use of descriptive statistics.

\section{Analysis}

Each building selected was analysed under the headings following;

3.1 Assessment of the Building Layout (Orientation) of the Selected Residential Buildings in Osogbo

Table 1. Building Layout

\begin{tabular}{|c|c|c|c|c|c|c|c|}
\hline \multicolumn{8}{|c|}{ *Layout by Building Design Type } \\
\hline \multicolumn{2}{|l|}{ Category } & Very bad & $\mathrm{Bad}$ & Fair & Good & Very good & Total \\
\hline \multirow{2}{*}{ Rooming Apartment } & $\mathrm{F}$ & 1 & 7 & 24 & 22 & 4 & 58 \\
\hline & $\%$ & 0.5 & 3.3 & 11.5 & 10.5 & 1.9 & 27.8 \\
\hline \multirow{2}{*}{ Apartment type } & $\mathrm{F}$ & 2 & 2 & 16 & 10 & 7 & 38 \\
\hline & $\%$ & 1.0 & 1.0 & 7.7 & 4.8 & 3.3 & 18.2 \\
\hline \multirow{2}{*}{ Duplex } & $\mathrm{F}$ & 0 & 0 & 12 & 13 & 3 & 28 \\
\hline & $\%$ & 0.0 & 0.0 & 5.7 & 6.2 & 1.4 & 13.4 \\
\hline \multirow{2}{*}{ Family bungalow } & $\mathrm{F}$ & 2 & 1 & 21 & 33 & 10 & 68 \\
\hline & $\%$ & 1.0 & 0.5 & 10.0 & 15.8 & 4.8 & 32.5 \\
\hline \multirow{2}{*}{ Traditional } & F & 0 & 1 & 8 & 4 & 3 & 17 \\
\hline & $\%$ & 0.5 & 0.5 & 3.8 & 1.9 & 1.4 & 8.1 \\
\hline \multirow{2}{*}{ Total } & $\mathrm{F}$ & 5 & 11 & 81 & 82 & 27 & 209 \\
\hline & $\%$ & 2.4 & 5.3 & 38.8 & 39.2 & 12.9 & 100 \\
\hline
\end{tabular}

*Layout - orientation on east-west axis with the long elevations facing north and south

Table 1 reveals that simple majority $(82,39.2 \%)$ of the total selected residential buildings had good layout. Among this proportion, $(33,15.8 \%)$ representing the simple majority in that group was observed from the family bungalow building design type, while the least proportion in this group $(4,1.9 \%)$ was observed from the traditional building design type. In addition, $(81,38.8 \%)$ of the total residential buildings surveyed had, their building layout as fair, with majority $(33,15.8 \%)$ representing the bungalow building design type. Residential buildings with very good layout accounted for $(27,12.9 \%)$ with majority $(10,4.8 \%)$ observed among the bungalow building design type. The least proportion of $(5,2.4 \%)$ represents the 
total proportion of residential buildings with very bad layout. Generally the result reveals that the building layout of the bungalow building design type was better compared to the other building- type surveyed.

\subsection{Assessment of the Adequacy of Spacing of Selected Residential Buildings in Osogbo}

Table 2. Spacing between buildings

\begin{tabular}{|l|l|l|l|l|l|l|l|}
\hline \multicolumn{7}{|c|}{ Adequacy of *Spacing by Building Design Type } \\
\hline Category & & Very inadequate & Inadequate & Fair & Adequate & Very adequate & Total \\
\hline Rooming Apartment & $\mathrm{F}$ & 29 & 26 & 0 & 3 & 0 & 58 \\
\cline { 2 - 9 } & $\%$ & 13.9 & 12.4 & 0.0 & 1.4 & 0.0 & 27.8 \\
\hline \multirow{3}{*}{ Apartment type } & $\mathrm{F}$ & 21 & 13 & 3 & 0 & 1 & 38 \\
\cline { 2 - 9 } & $\%$ & 10.0 & 6.2 & 1.4 & 0.0 & 0.5 & 18.2 \\
\hline \multirow{3}{*}{ Duplex } & $\mathrm{F}$ & 5 & 4 & 9 & 9 & 1 & 28 \\
\cline { 2 - 9 } & $\%$ & 2.4 & 1.9 & 4.3 & 4.3 & 0.5 & 13.4 \\
\hline \multirow{3}{*}{ Family bungalow } & $\mathrm{F}$ & 30 & 26 & 0 & 11 & 0 & 68 \\
\cline { 2 - 8 } & $\%$ & 14.4 & 12.4 & 0.0 & 5.3 & 0.0 & 32.5 \\
\hline \multirow{3}{*}{ Traditional } & $\mathrm{F}$ & 13 & 3 & 1 & 0 & 0 & 17 \\
\cline { 2 - 8 } & $\%$ & 6.2 & 1.4 & 0.5 & 0.0 & 0.0 & 8.1 \\
\hline \multirow{2}{*}{ Total } & $\mathrm{F}$ & 98 & 72 & 13 & 23 & 2 & 209 \\
\cline { 2 - 8 } & $\%$ & 46.9 & 34.4 & 6.2 & 11.0 & 1.0 & 100 \\
\hline
\end{tabular}

*Spacing- spaces between long parallel rows of buildings should be five times the height of the buildings or more

Table 2 reveals that the simple majority of $(98,46.9 \%)$ with respect to distance between buildings, of the total selected residential buildings were very inadequate. Of this proportion, the rooming apartment and the bungalow building design type accounted for the majority of the residential building in this category, representing approximately $(14.0 \%)$ each of the total residential building in this category. The building design type with the least proportion (5, $2.4 \%$ ) of representation in this category was observed among the duplex building design type. In addition, $(72,34.4 \%)$ of the total residential buildings surveyed had inadequate spacing, with the family bungalow and rooming apartment building design type also accounting for the majority $(12.4 \%)$ each in this category. However, just $(23,11.0 \%)$ of the residential building surveyed had adequate spacing, with the family bungalow and the duplex building design type accounting for the majority $(11,5.3 \%)$ and $(9,4.3 \%)$ respectively of the residential building in this category. Residential buildings with very adequate spacing accounted for just $(2,1.0 \%)$ observed from the duplex $(1,0.5 \%)$ and apartment $(1,0.5 \%)$ building design type. Generally the result reveals that the rooming apartment and the family bungalow building design type dominate the proportion of residential buildings surveyed which had inadequate spacing between buildings, while the duplex building type generally had better spacing compared to the other residential building in the study area. 
3.3 Assessment of the Adequacy of Air Movement of Selected Residential Buildings in Osogbo

Mahoney Tables indicated that rooms in buildings can be single or double banked. If air movement is essential for comfort for more than two months, rooms may be single banked. If air movement is needed for not more than one or two months rooms may be double banked. If there are months when air movement is not essential but desirable rooms should allow for temporary cross ventilation for example it could be double banked with large interconnecting doors (Mahoney Tables). On this basis the selected residential buildings were evaluated.

Table 3. Air Movement

\begin{tabular}{|l|l|l|l|l|l|l|l|}
\hline \multicolumn{7}{|c|}{ Adequacy of *Air Movement by Building Design Type } \\
\hline Category & & Very inadequate & inadequate & Fair & Adequate & Very adequate & Total \\
\hline \multirow{2}{*}{ Rooming Apartment } & $\mathrm{F}$ & 4 & 0 & 17 & 35 & 2 & 58 \\
\cline { 2 - 9 } & $\%$ & 1.9 & 0.0 & 8.1 & 16.7 & 1.0 & 27.8 \\
\hline \multirow{3}{*}{ Apartment type } & $\mathrm{F}$ & 10 & 0 & 8 & 12 & 8 & 38 \\
\cline { 2 - 9 } & $\%$ & 4.8 & 0.0 & 3.8 & 5.7 & 3.8 & 18.2 \\
\hline \multirow{3}{*}{ Duplex } & $\mathrm{F}$ & 1 & 0 & 8 & 12 & 3 & 28 \\
\cline { 2 - 8 } & $\%$ & 0.5 & 0.0 & 3.8 & 5.7 & 3.3 & 13.4 \\
\hline Family bungalow & $\mathrm{F}$ & 18 & 0 & 4 & 26 & 20 & 68 \\
\cline { 2 - 8 } & $\%$ & 8.6 & 0.0 & 1.9 & 12.4 & 9.6 & 32.5 \\
\hline \multirow{3}{*}{ Traditional } & $\mathrm{F}$ & 0 & 2 & 4 & 8 & 3 & 17 \\
\cline { 2 - 8 } & $\%$ & 0.0 & 1.0 & 1.9 & 3.8 & 1.4 & 8.1 \\
\hline \multirow{2}{*}{ Total } & $\mathrm{F}$ & 33 & 2 & 41 & 93 & 40 & 209 \\
\cline { 2 - 8 } & $\%$ & 15.8 & 1.0 & 19.6 & 44.5 & 19.1 & 100 \\
\hline
\end{tabular}

*Air Movement- rooms should be single banked with openings facing north-south direction, if double banked rooms should allow for cross ventilation and spaces should be interconnected.

Table 3 above assesses the adequacy of air movement in the selected residential buildings in the study area when air movement is needed for more than two months. The result reveals air movement of simple majority $(93,44.5 \%)$ of the total surveyed residential buildings was adequate. Of this proportion, the rooming apartment and the bungalow building design type accounted for the majority of the residential buildings in this category, accounting for approximately $(35,16.7 \%)$ and $(26,12.4 \%)$ respectively. Although nearly all rooming apartment building design type are double banked, $16.7 \%$ of the building type shows interconnectivity with the opposite row of rooms hence, allowing air to move freely from one bank into the other while the $12.4 \%$ of the bungalow building design type allows for cross ventilation. The building design type with the least proportion $(8,3.8 \%)$ of representation in this category was observed among the traditional building design type. Furthermore, (41, $34.4 \%$ ) of the total residential buildings surveyed had fair air movement in their buildings, with the rooming apartment building design type accounting for the majority $(17,8.1 \%)$ of the residential building in this category. This was closely followed by residential buildings with very adequate air movement accounting for (40, 19.1\%), with majority $(20,9.6 \%)$ of the residential buildings in this category observed among the family bungalow building type, 
while the building design type with the least proportion was observed from the rooming apartment and the traditional building-type, accounting for $(2,1.0 \%)$ and $(3,1.4 \%)$ respectively. Besides, the bungalow building design type topped the list (18 out of 33) of building design type with very inadequate air movement, representing (8.3\%). Generally, the result reveals that the rooming apartment building design type dominate the proportion of residential buildings surveyed which had adequate air movement in the house compared to other residential buildings in the study area.

\subsection{Assessment of the Adequacy of Openings of Selected Residential Buildings in Osogbo}

Mahoney indicated that openings should be between 40-80 per cent north and south walls if thermal storage is required for less than two months. Openings should be protected from sun, glare and rain. Openings in residential buildings for ventilation were measured and assessed by experts through rating. The result is presented in the Table 4.

Table 4. Air Movement

\begin{tabular}{|l|l|l|l|l|l|l|l|}
\hline \multicolumn{7}{|c|}{ Adequacy of *Openings by Building Design Type } \\
\hline Category & & Very inadequate & Inadequate & Fair & Adequate & Very adequate & Total \\
\hline Rooming Apartment & $\mathrm{F}$ & 1 & 3 & 17 & 30 & 7 & 58 \\
\cline { 2 - 9 } & $\%$ & 0.5 & 1.4 & 8.1 & 14.4 & 3.3 & 27.8 \\
\hline \multirow{3}{*}{ Apartment type } & $\mathrm{F}$ & 9 & 0 & 3 & 16 & 10 & 38 \\
\cline { 2 - 9 } & $\%$ & 4.3 & 0.0 & 1.4 & 7.7 & 4.8 & 18.2 \\
\hline \multirow{3}{*}{ Duplex } & $\mathrm{F}$ & 2 & 0 & 4 & 13 & 9 & 28 \\
\cline { 2 - 9 } & $\%$ & 1.0 & 0.0 & 1.9 & 6.2 & 4.3 & 13.4 \\
\hline Family bungalow & $\mathrm{F}$ & 20 & 0 & 1 & 36 & 11 & 68 \\
\cline { 2 - 8 } & $\%$ & 9.6 & 0.0 & 0.5 & 17.2 & 5.3 & 32.5 \\
\hline \multirow{3}{*}{ Traditional } & $\mathrm{F}$ & 1 & 1 & 7 & 5 & 3 & 17 \\
\cline { 2 - 8 } & $\%$ & 0.5 & 0.5 & 3.3 & 2.4 & 1.4 & 8.1 \\
\hline \multirow{2}{*}{ Total } & $\mathrm{F}$ & 33 & 4 & 32 & 100 & 40 & 209 \\
\cline { 2 - 8 } & $\%$ & 15.8 & 1.9 & 15.3 & 47.8 & 19.1 & 100 \\
\hline
\end{tabular}

*Openings- openings should be $40-80 \%$ of the north and south walls

Table 4 reveals that the opening (with respect to window/wall ratio) of the simple majority $(100,47.8 \%)$ of the total selected residential buildings was adequate. However, of this proportion, the family bungalow and rooming apartment building design type accounted for the majority of the residential building in this category, representing $(36,17.2 \%)$ and $(30$, $14.4 \%)$ respectively. The building design type with the least proportion $(5,2.4 \%)$ in this category was observed among the traditional building design type. On the contrary, the family bungalow building design type accounted for the majority (20 out of the 33) total residential buildings surveyed with very inadequate openings in their buildings, representing (9.6\%) of residential building in this category. The bungalow building design type also topped the list (11 out of 40) of building design type with very adequate openings, closely followed by the apartment building design type (10 out of 40) and representing (5.3\%) and $(4.8 \%)$ respectively. Generally, the result reveals that majority of the residential buildings 
surveyed (140 out of 209 sampled buildings), representing approximately (70.0\%) of the surveyed residential buildings had adequate openings in their buildings.

\subsection{Assessment of the Material for External Walls of Selected Residential Buildings in Osogbo}

External walls should be light with small low heat transmittance. Materials for external walls were assessed by expert and rated based on observation theoretical calculations in line with ISO 6946. The result is presented in the Table below.

Table 5. External Walls

\begin{tabular}{|l|l|l|l|l|l|l|l|}
\hline \multicolumn{2}{|c|}{} & \multicolumn{7}{|c|}{ *Wall Material by Building Design Type } \\
\hline Category & & Very Good & Good & Fair & Bad & Very Bad & Total \\
\hline Rooming Apartment & $\mathrm{F}$ & 50 & 0 & 1 & 7 & 0 & 58 \\
\cline { 2 - 8 } & $\%$ & 24.0 & 3.4 & 0.5 & 0.0 & & 27.9 \\
\hline \multirow{2}{*}{ Apartment type } & $\mathrm{F}$ & 34 & 1 & 3 & 0 & 0 & 38 \\
\cline { 2 - 8 } & $\%$ & 16.3 & 0.5 & 1.4 & 0.0 & & 18.3 \\
\hline Duplex & $\mathrm{F}$ & 22 & 3 & 1 & 0 & 0 & 27 \\
\cline { 2 - 8 } & $\%$ & 11.1 & 1.4 & 0.5 & 0.0 & & 13.0 \\
\hline Family bungalow & $\mathrm{F}$ & 60 & 1 & 5 & 2 & 0 & 68 \\
\cline { 2 - 8 } & $\%$ & 28.8 & 0.5 & 2.4 & 1.0 & & 32.5 \\
\hline Traditional & $\mathrm{F}$ & 8 & 0 & 1 & 8 & 0 & 17 \\
\cline { 2 - 8 } & $\%$ & 3.8 & 0.1 & 0.5 & 3.8 & & 8.1 \\
\hline Total & $\mathrm{F}$ & 175 & 5 & 11 & 17 & 0 & 208 \\
\cline { 2 - 8 } & $\%$ & 84.1 & 2.4 & 5.3 & 8.2 & & 100 \\
\hline
\end{tabular}

*Walls- external walls should be light with a small heat capacity

Table 5 reveals that the majority of the walls $(175,84.1 \%)$ of the total surveyed residential buildings were made with very good materials. However, of this proportion, the family bungalow and the rooming apartment building design type accounted for the majority of the residential building in this category, representing $(60,28.8 \%)$ and $(50,24.0 \%)$ respectively. The building design type with the least proportion $(8,3.8 \%)$ in this category was observed among the traditional. Furthermore, just $(10,4.8 \%)$ of the total residential buildings surveyed had bad walls. Out of this number, the traditional building design type accounted for majority ( 8 out of $10,3.8 \%$ ) with bad walls, while the family bungalow accounted for the remaining (2, $1.0 \%$ ) with bad walls. Generally the result reveals that significant proportion of the residential buildings surveyed (187, out of 209) representing approximately $(90.0 \%)$ of the surveyed residential buildings had their buildings made with good wall materials.

\subsection{Assessment of Roofs for Selected Residential Buildings in Osogbo}

Table 6 below reveals that the roofs of simple majority $(72,34.4 \%)$ of the total surveyed residential buildings were bad. However, of this proportion, the rooming apartment and the family bungalow building-type accounted for the majority of the residential building in this category, representing $(34,16.3 \%)$ and $(17,8.1 \%)$ respectively. The building design type with 
the least proportion $(4,1.9 \%)$ each in this category was observed among the duplex and traditional building design type. In addition, the rooming apartment building design type dominates the category of residential buildings with very bad roofs. Furthermore, $(32,15.3 \%)$ of the total residential buildings surveyed had very good roofs. Out of this number, the duplex building design type accounted for majority (18 out of 32 houses), and representing (8.6\%). The only building design type that was not represented in this category was the rooming apartment building design type.

Table 6. Roofs

\begin{tabular}{|l|l|l|l|l|l|l|l|}
\hline \multicolumn{7}{|c|}{ *Roof by Building Design Type } \\
\hline Category & & Very Bad & Bad & Fair & Good & Very Good & Total \\
\hline Rooming Apartment & $\mathrm{F}$ & 19 & 34 & 1 & 0 & 0 & 58 \\
\cline { 2 - 9 } & $\%$ & 9.1 & 16.3 & 0.0 & 0.0 & 0.0 & 27.8 \\
\hline \multirow{2}{*}{ Apartment type } & $\mathrm{F}$ & 10 & 13 & 5 & 5 & 5 & 38 \\
\cline { 2 - 9 } & $\%$ & 4.8 & 6.2 & 2.4 & 2.4 & 2.4 & 18.2 \\
\hline \multirow{3}{*}{ Duplex } & $\mathrm{F}$ & 0 & 4 & 0 & 6 & 18 & 28 \\
\cline { 2 - 9 } & $\%$ & 0.0 & 1.9 & 0.0 & 2.9 & 8.6 & 13.4 \\
\hline Family bungalow & $\mathrm{F}$ & 0 & 17 & 16 & 25 & 7 & 68 \\
\cline { 2 - 8 } & $\%$ & 0.0 & 8.1 & 7.7 & 12.0 & 3.3 & 32.5 \\
\hline Traditional & $\mathrm{F}$ & 4 & 4 & 3 & 4 & 2 & 17 \\
\cline { 2 - 8 } & $\%$ & 1.9 & 1.9 & 1.4 & 1.9 & 1.0 & 8.1 \\
\hline Total & $\mathrm{F}$ & 33 & 72 & 25 & 40 & 32 & 209 \\
\cline { 2 - 8 } & $\%$ & 15.8 & 34.4 & 12.0 & 19.1 & 15.3 & 100 \\
\hline
\end{tabular}

*Roof- cool roofs: Steep slope/reflective colour/low transmittance value

\section{Discussion}

Janda (2011) identifies influences on a building energy load. The study listed building envelope, occupant behaviour, micro-generation and plug loads as the influences that affect energy use. Likewise, Milne and Labib, (1990) stated that buildings vary greatly in their energy use depending on building design, local climate and socio-economic. An energy sensitive building involves a synergy between the climate and the building envelope. It is a measure of how a building is designed to be climate responsive. The influence of climate on active energy consumed in residential buildings is magnified by a building design. The more a building envelope is climate responsive the more is the energy reduction. In Nigeria, Ayinla et al (2013) examined bioclimatic performance of various residential building types in the traditional core area of Ogbomoso in a warm humid climate. The methodology for the study involved the use of Mahoney Table. Four residential building designs were sampled namely, Traditional Compound, Modified Traditional Compound, Brazilian rooming house and Flat/Duplex. The result revealed that air movement is highly essential to reduce discomfort. There is also inadequate spacing between buildings and poor building orientation.

Likewise, Lawal and Ojo (2011) assessed the thermal performance of residential buildings in Ibadan. A field investigation was conducted on four buildings with different designs. The 
result of the findings showed that there is a very strong relationship among the independent factors (that is the Building types) on the dependent factor (ambient temperature) and the effect of the building types is significant on the ambient temperature. They found that Thermal performance and energy use of the buildings are proportional to details of designs of the building, climate responsive energy design parameters, the use of site, details of microclimate and nature and magnitude of the fabrics. The study recommended the provision of plasters on Adobe walls, ceilings, shading, proper positioning of the buildings and increase in the mass contents of the walls of the buildings to improve the thermal comfort of occupants. Lawal and Ojo (2011) concluded that adequate consideration must be given to effective building architecture and appropriate finishes operations on walls in order to achieve internal comfort for the occupants.

Furthermore, Su (2011) conducted study on the impact of design factors on house energy use. Su concluded that successful energy house design for energy consumption reduction should take the different design factors related to architectural features, building elements and building materials into consideration as a whole. Ignoring one design factor could affect the entire house design strategies in terms of energy sensitivity.

All the previous studies reviewed corroborated this study findings and emphasize that layout, air movement, design factors materials, openings, spacing and roofs are essential for a climatic responsive and energy sensitive designs. Meanwhile an insight on how to synergise the various designs short comings to evolve a simple energy sensitive design is lacking.

However, Borda-Diaz et al (1989) evolved a model. The approach and the materials suggested in the study were quite eco-friendly but the model does not reflect an urban setting. A typical urban setting in Nigeria is a combination of contemporary and traditional designs. On this basis this study model takes into cognisance the dominant building material (that is; the sandcrete blocks) and the urban setting.

\section{Conclusion}

The comparative advantages from the analysis and the observed influence of the temperature rise indoor as a result of increased outdoor temperature on the buildings were merged to evolve an energy sensitive design frame work. The assessment of the physical characteristics of the residential buildings indicated that the design of buildings be improved upon in the areas of spaces between buildings, external walls protection, air movement, roofing, and layout. Spaces between buildings were very inadequate likewise the result for the assessment of the roofs indicated that the majority of the roofs in the study area were not cool roofs. Good wind driven ventilation design must be achieved in order for the air movement to be effective. Although nearly all rooming apartment building design type were double banked, the building-type shows interconnectivity with the opposite row of rooms hence, allowing air to move freely from one bank into the other. On this basis the framework evolved an open space at the centre surrounded by rooms having fenestration opposite each other, opening into the terrace around the courtyard/atrium and around the building. Though a large number of the buildings have their external walls constructed of cement plastered Sandcrete hollow blocks/sancrete hollow blocks but to further reduce the heat flow into the building during a 


\section{Macrothink}

hot summer day. A terrace is introduced round the building to prevent the external walls from direct radiation from the sun. Figure 1 and 2 represents a framework plan and section developed from the selected researched buildings in a warm humid climate. The framework included a terrace around the building and around the courtyard/atrium to reduce temperature indoor, large concentrated air inlet and outlet along the length of the building on east west axis with clearstory at the roof level of the airspace within the building framework. However the framework is still subject to further research work in order to determine the wideness of the terrace $(x$ and $y)$, airspace $(L)$ and the height of the airspace $(k)$.

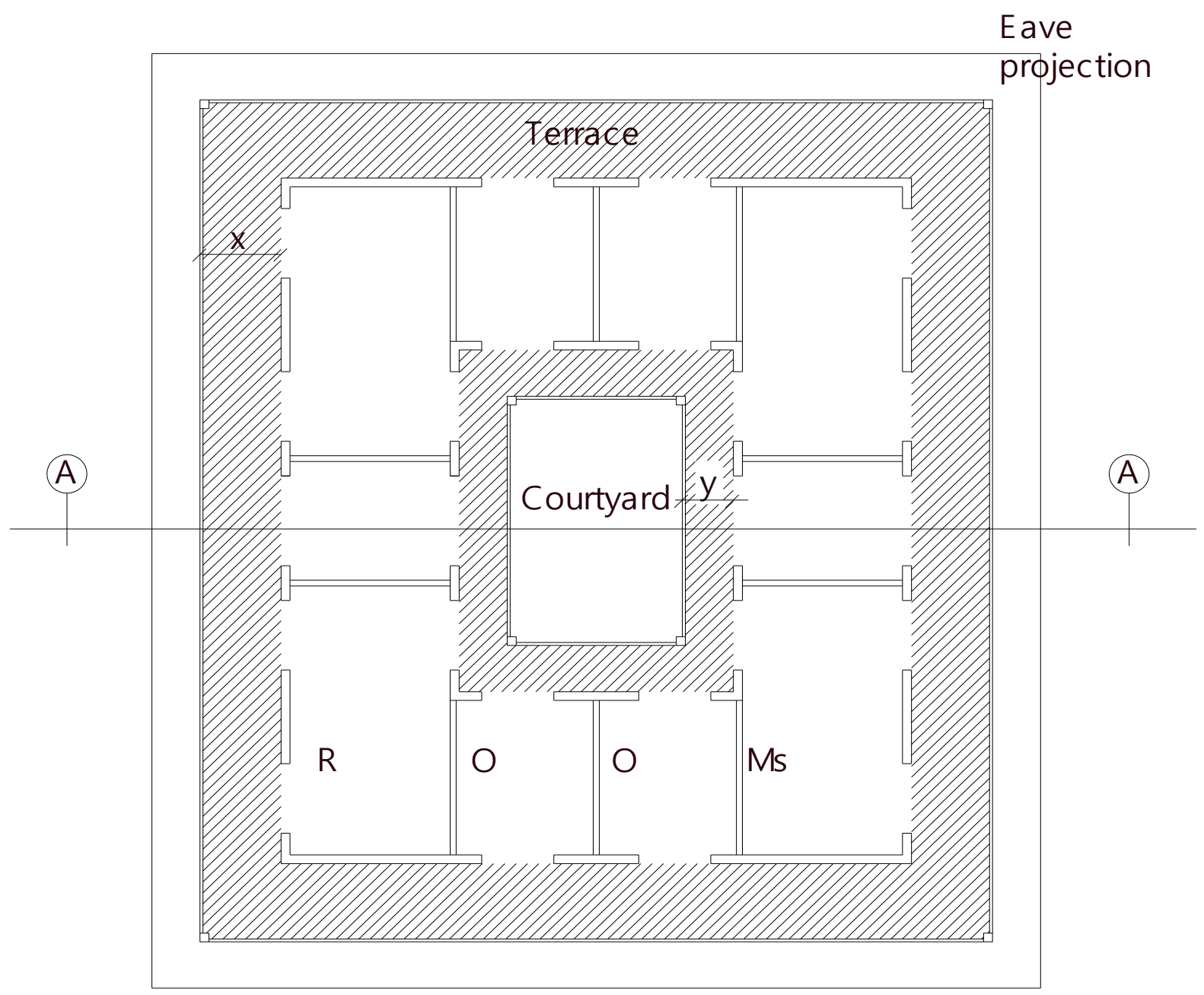

Figure 1. Energy Sensitive Designs: Proposed Model for Residential Buildings in Warm Humid Climate 


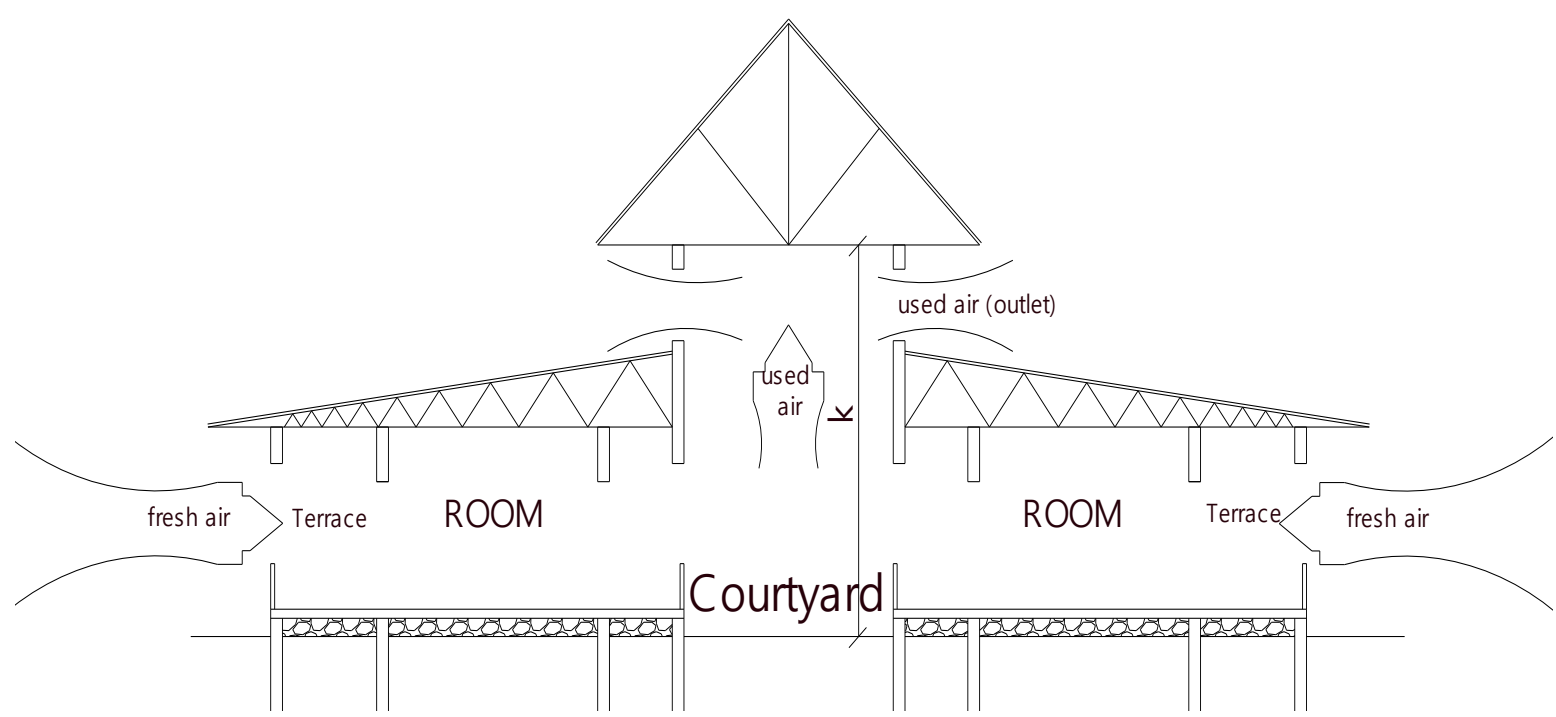

Figure 2. Section A.A- Energy Sensitive Designs: Proposed Model for Residential Buildings in Warm Humid Climate

\section{References}

Akinbami, J. F., \& Lawal, A. (2009, June). Opportunities and challenges to electrical energy conservation and $\mathrm{CO} 2$ emissions reduction in Nigeria's building sector'. In Fifth Urban Research Symposium, Cities and Climate Change: Responding to an Urgent Agenda (pp. 28-30).

Ajibola, K. (2001). Design for comfort in Nigeria-a bioclimatic approach. Renewable energy, 23(1), 57-76. http://dx.doi.org/10.1016/S0960-1481(00)00113-0

Ayinla, A. K., Olaniyan S. A., \& Okeyinka Y. R. (2013). Bio-climatic characteristics of residential building types in the traditional core of Ogbomoso, South West Nigeria. International Journal of Science, Environmentand Technology, 2(6), 1462-1478.

Borda-Diaz, N., Mosconi, P. I., \& Vazquez, J. A. (1989). Passive cooling strategies for a building prototype design in a warm-humid tropic climate. Solar \& wind technology, 6(4), 389-400. http://dx.doi.org/10.1016/0741-983X(89)90058-1

Folaranmi, A. O., Philip, A., Stephen, O., \& Amina, B. (2013). Bioclimatic Design Principle a Solution to Thermal Discomfort in Minna Residences, Niger State Nigeria. Journal of Environment and Earth Science, 3(12), 45-51.

Givoni B. (1981). Man, Climate and architecture. London: Applied Science Publishers Ltd, 7-184.

Hyde, R. (2013). Climate responsive design: a study of buildings in moderate and hot humid climates. Taylor and Francis.

Janda, K. B. (2011). Buildings don't use energy: people do. Architectural Science Review, 54(1), 15-22. http://dx.doi.org/10.3763/asre.2009.0050 
Kamal, M. A. (2012). An Overview of Passive Cooling Techniques in Buildings: Design Concepts and Architectural Interventions.

Lawal, A. F (2013). Climate Responsive Approach to Building Design for Comfort in Warm-Humid Climate. International Journal of Engineering and Technology Vol. 3 No. 1.

Lawal, A. F., \& Ojo, O. J. (2011). Assessment of Thermal Performance of Residential Buildings in Ibadan Land, Nigeria. Journal of Emerging Trends in Engineering and Applied Sciences (JETEAS), 2(4), 581-586.

Milne, M., \& Labib, T. (1990). Tools for designing climate responsive buildings. In Proceedings at ACADIA (Vol. 90).

Ogundipe, A. A., \& Apata, A (2013). Electricity Consumption and Economic Growth in Nigeria. Journal of Business Management and Applied Economics.

Oyedepo, S. O. (2012). Efficient energy utilization as a tool for sustainable development in Nigeria. International Journal of Energy and Environmental Engineering, 3(1), 1-12. http://dx.doi.org/10.1186/2251-6832-3-11

Rikko, L. S., \& Gwatau, D. (2011). The Nigerian architecture: The trend in housing development. Journal of Geography and Regional Planning, 4(5), 273-278.

$\mathrm{Su}$, B. (2011). The impact of passive design factors on house energy efficiency. Architectural Science Review, 54(4), 270-276. http://dx.doi.org/10.1080/00038628.2011.613638

Szokolay, V. S. (2014). Introduction to Architectural science: the basis of sustainable design. 2nd Ed. Elsevier ltd.

UNI EN ISO 6946 - Building components and building elements; Thermal resistance and thermal transmittance. [Online] Available: www.uni.com (July 30, 2015)

\section{Glossary}

The National Bureau of Statistics NBS (2010): Government agency

Independent National Electoral Commission (INEC): Government agency

The National Population Commission (NPC): Government agency

F: Frequency of building type surveyed

$\%$ : Percentage 


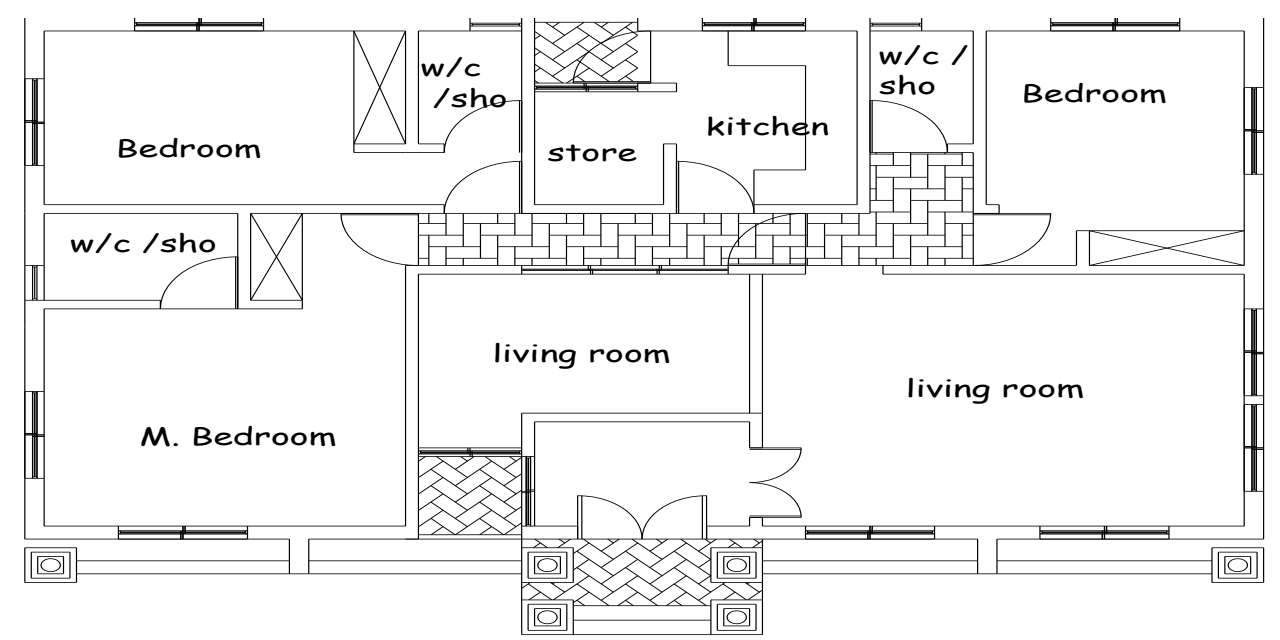

An Example of an Existing Bungalow Floor Plan
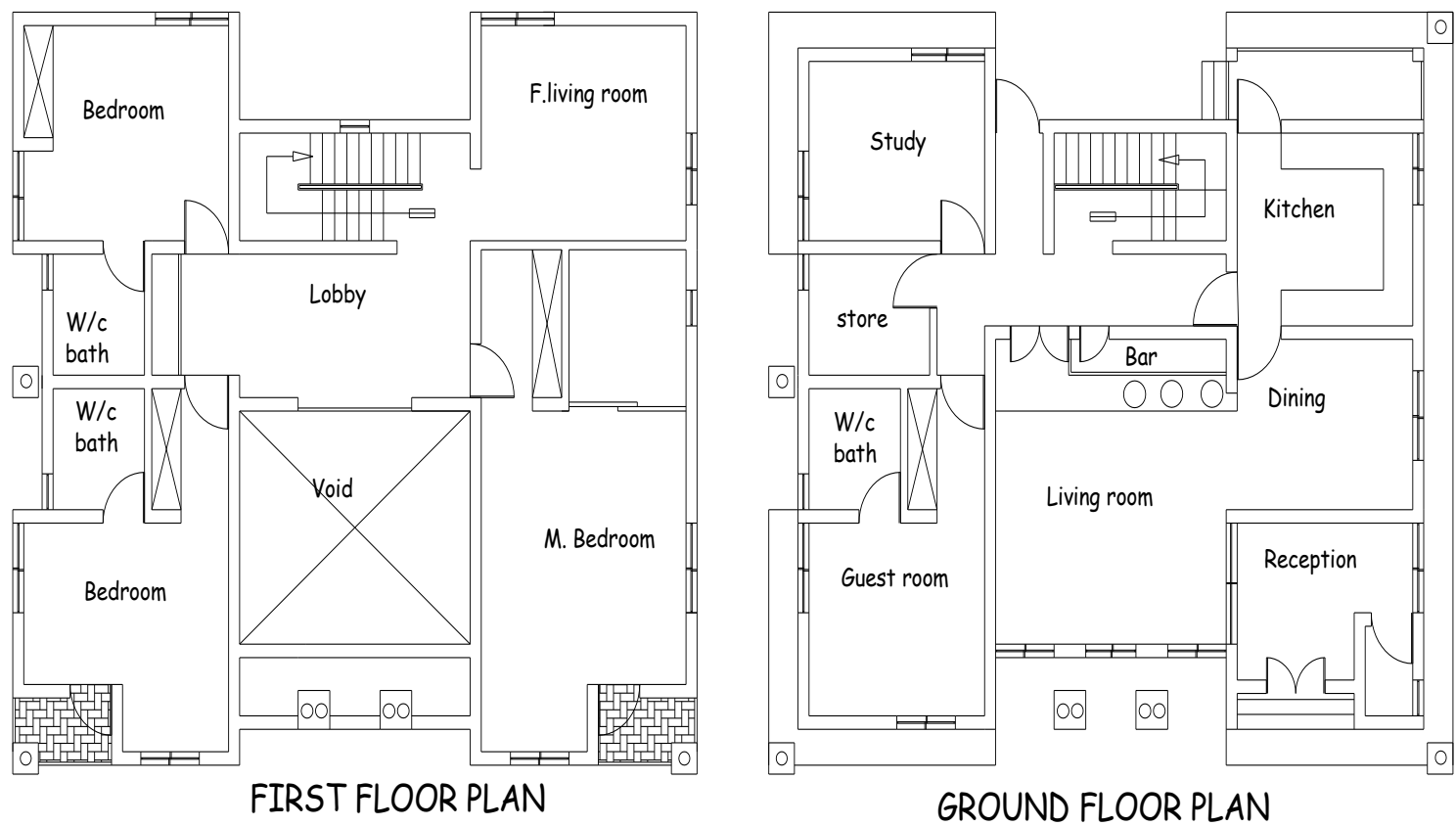

An Example of Duplex Floor Plans 


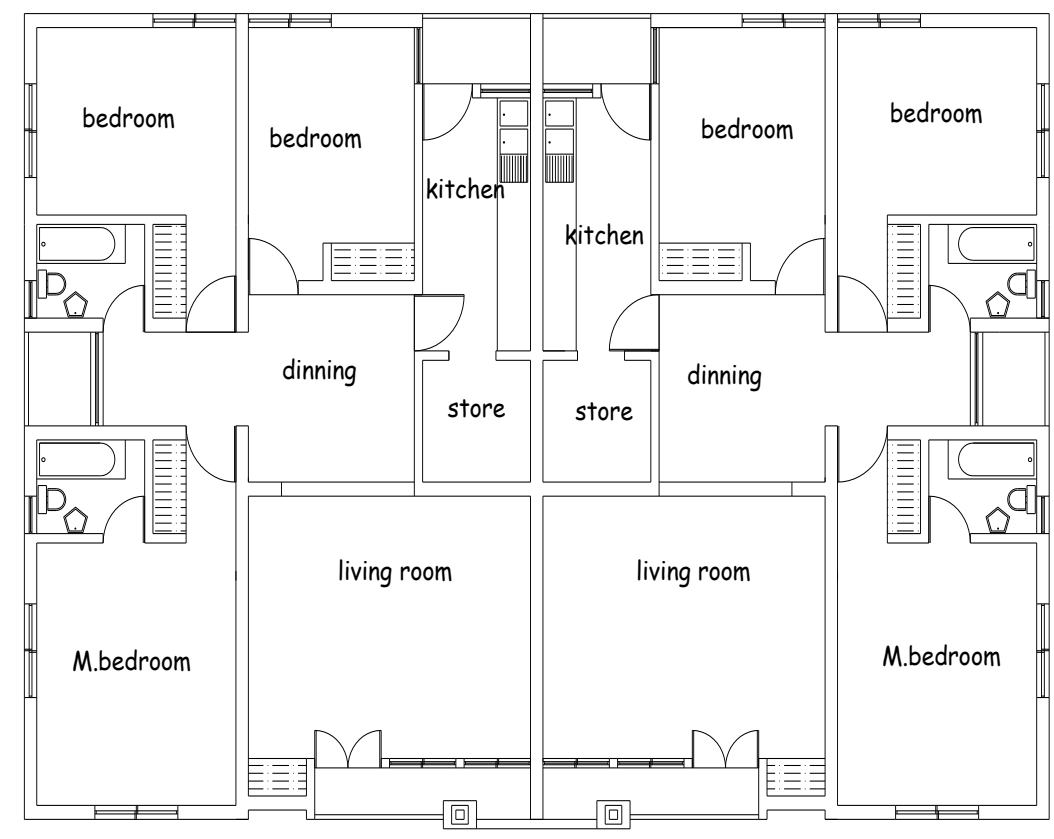

An Example of Apartment Floor Plan

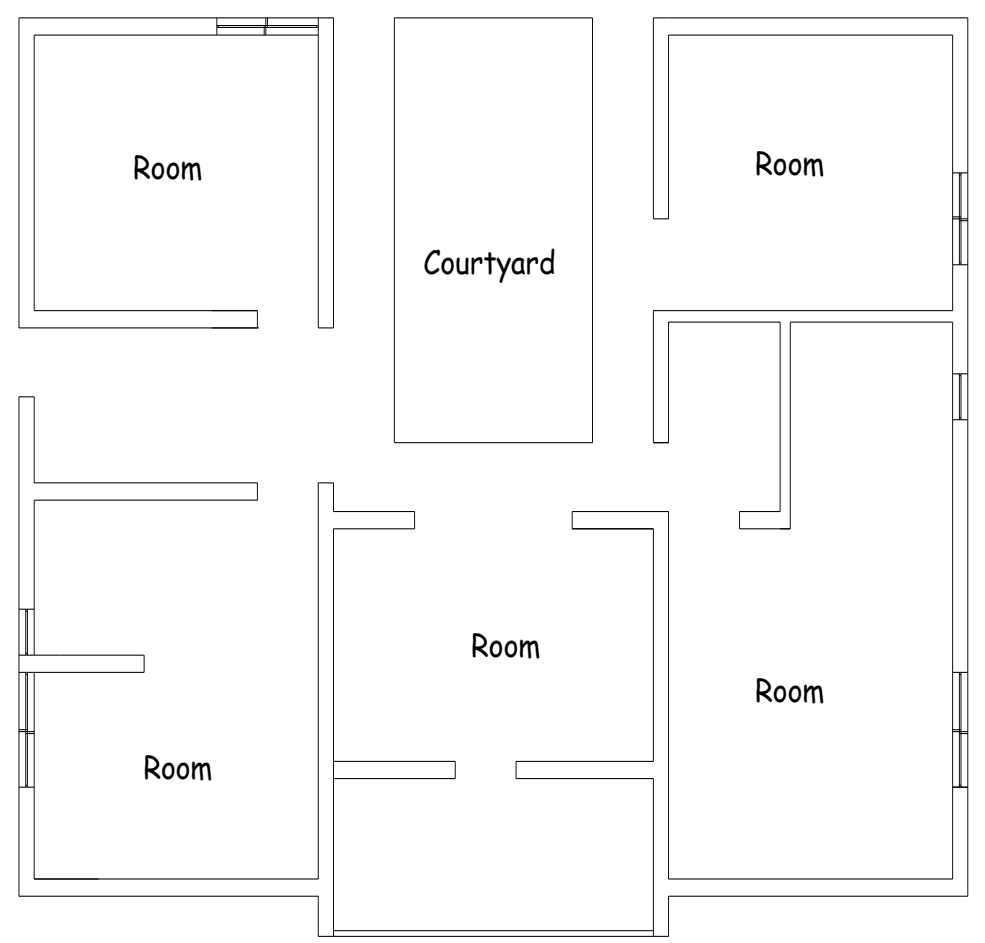

An Example of a Traditional Floor Plan 


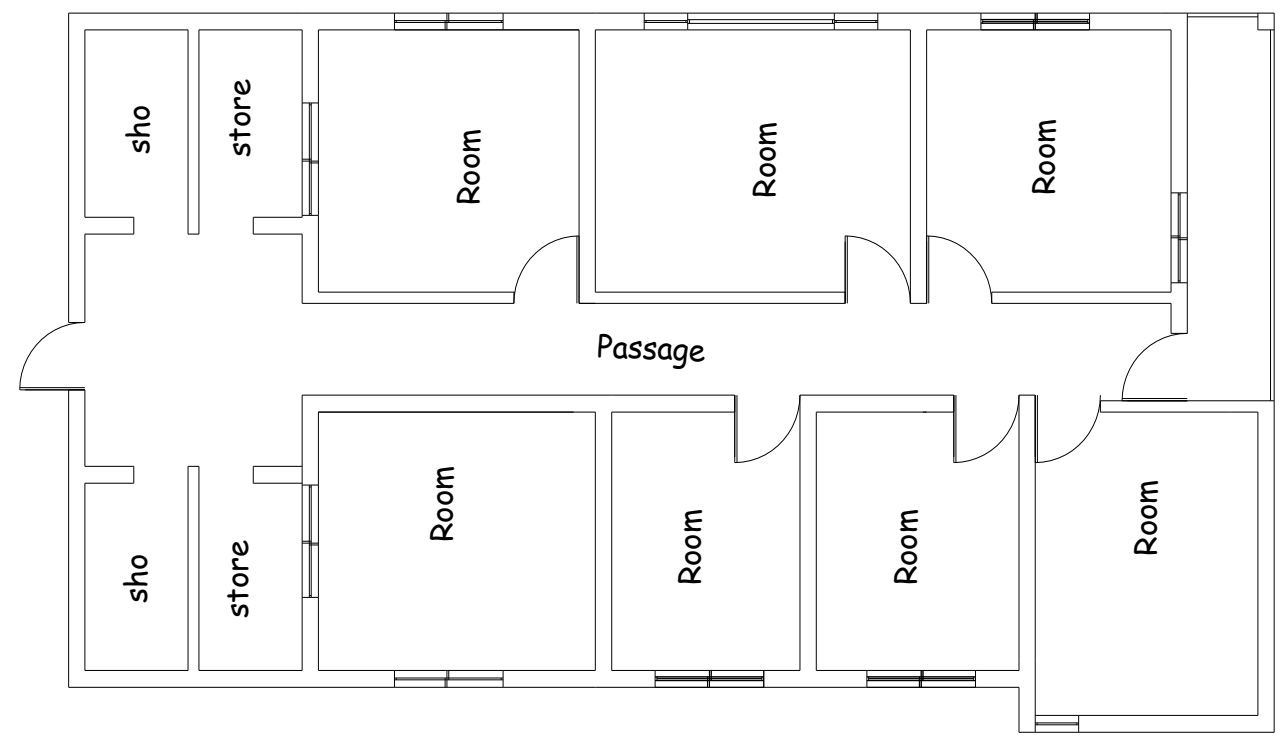

An Example of a Rooming Apartment Floor Plan

\section{Appendix}

\section{TO BE FILLED ON FIELD}

Building's identification number

Aa1

\begin{tabular}{|c|l|l|l|l|l|}
\hline \multicolumn{1}{|c|}{ LAYOUT } & \multicolumn{1}{|l|}{} \\
\cline { 1 - 4 } Score/rating & $(-2)$ Very bad & $(-1)$ bad & (0)Fairly good & (1)good & (2)very good \\
\hline
\end{tabular}

\begin{tabular}{|c|l|l|l|l|l|}
\hline \multicolumn{1}{|c|}{ SPACING } & \multicolumn{1}{|l}{$(1)$} & $(2)$ \\
\cline { 1 - 3 } Score/rating & $(-2)$ & $\begin{array}{l}(-1) \\
\text { inadequate }\end{array}$ & $\begin{array}{l}(0) \\
\text { fairly adequate }\end{array}$ & $\begin{array}{l}(1) \\
\text { adequate }\end{array}$ & \begin{tabular}{l} 
very adequate \\
\hline
\end{tabular}
\end{tabular}

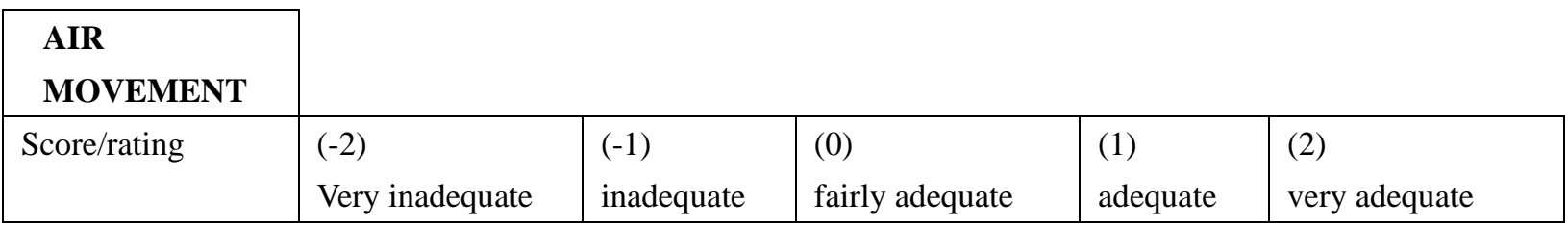

\begin{tabular}{|l|l|l|l|l|l|}
\hline \multicolumn{1}{|c|}{ OPENINGS } & \multicolumn{1}{|c|}{$(-1)$} & $(0)$ & $(1)$ & $(2)$ \\
\cline { 1 - 3 } Score/rating & $(-2)$ & $\begin{array}{l}(-1) \\
\text { inadequate }\end{array}$ & fairly adequate & $\begin{array}{l}\text { adequate } \\
\text { very inadequate }\end{array}$ &
\end{tabular}

\begin{tabular}{|l|l|l|l|l|l|}
\hline \multicolumn{1}{|c|}{ WALLS } & \multicolumn{1}{|l|}{} \\
\hline Score/rating & (-2)Very bad & $(-1)$ bad & (0)Fairly good & (1)good & (2)very good \\
\hline
\end{tabular}

\begin{tabular}{|c|l|l|l|l|l|}
\hline ROOFS & \multicolumn{1}{|l|}{} \\
\hline Score/rating & (-2)Very bad & $(-1)$ bad & (0)Fairly good & (1)good & (2)very good \\
\hline
\end{tabular}




\section{Macrothink \\ Environmental Management and Sustainable Development \\ ISSN 2164-7682}

\section{Copyright Disclaimer}

Copyright for this article is retained by the author(s), with first publication rights granted to the journal.

This is an open-access article distributed under the terms and conditions of the Creative Commons Attribution license (http://creativecommons.org/licenses/by/3.0/). 